\title{
Tumor Promoter Induced Gene
}

National Cancer Institute

\section{Source}

National Cancer Institute. Tumor Promoter Induced Gene. NCI Thesaurus. Code C18587.

Tumor promoter induced genes are expressed shortly after cell exposure to tumor promoters. 